\title{
Canadian Films: What Are We to Make of Them?
}

\author{
By Gerald Pratley
}

Spring 1998 Issue of KINEMA

This technically fine picture was shot in British Columbia, but care seems to have been taken to eradicate any sign of Canadian identity in the story's setting, which is simply generic North American.

Film critic Derek Elley in his review of Mina Shum's Drive,

She Said in Variety, Dec. 22, 1997.

NO MATTER to what segment of society individuals may belong within the public at large most of those interested in the arts are contemplating what to make of Canadian cinema. Among indigent artists, outof-work actors, struggling writers, publishers and bookshop proprietors, theatregoers and movie enthusiasts, the question being asked is, what do we expect from Canadian movies? The puzzle begins when audiences, after being subjected to a barrage of media publicity and a frenzy of flag waving, which would have us believe that Canadian movies and tv programmes are among the best in the world, discover they are mostly embarrassingly bad.

Except that is, films made in Québec. Yet even here the decline into worthlessness over the past two years has become apparent. It is noticeable that, when the media in the provinces other than Québec talk about Canadian films, they are seldom thinking of those in French. This means that we are forced, when talking about Canadian cinema, into a form of separation because Québec film making is so different from "ours", making it impossible to generalize over Canadian cinema as a whole.

If we are to believe everything the media tells us then David Cronenberg, whose work is morbid, Atom Egoyan, whose dabblings leave much to be desired, Guy Maddin, who is lost in his own dreams, and Patricia Rozema, who seldom seems to know what she is doing, are among the world's leading filmmakers. These directors have become fashionable on the international festival circuit and media darlings at home. In the company of others, they have created a cult following and spend much of their time travelling around explaining their films, returning to obtain more grants from Telefilm to make more films that have little to do with Canada. Denys Arcand, Gilles Carle, André Melancon, Micheline Lanctôt, André Forcier, Robert Lepage, and other talented Québec filmmakers receive occasional mentions. Conversely it must be said that English-speaking directors seldom get mentioned in the Québec media, but given their disappointing record this is understandable.

What then should we expect from Canadian films? In describing films made in this country as Canadian what does this mean? Here it should be pointed out that this consideration applies mainly to those productions called " feature films" which are works of fiction (albeit containing truth and realism about the human condition; whose truth and realism are a constant matter of debate) written and directed (at times, regrettably by the same person) with its characters portrayed by actors. These motion pictures can be costly to make in this country, with budgets running from $\$ 5 \mathrm{~m}$ to $\$ 25 \mathrm{~m}$-- although inexpensive by Hollywood standards. Our producers, who are only in film as a business to make money rather than to put their country on the screen, use our small market as a reason to concentrate on pseudo-American films they are certain will show profits from the US market. They seldom do, but producers never learn. To spend more than these sums on a truly Canadian picture is to invite financial loss unless it finds wide public acceptance in this country.

Certain Québec films, economically made and popular with Québecois audiences, have returned their costs with profits in their own province alone. (Les Boys is the latest example.) To find the money to make these films, producers apply to Telefilm, the Federal film funding agency, to similar organizations in the provinces and to a tangle of other private and government funding programmes for cinema, tv and cable. Heaven knows how much this costs, the reports on money spent being so complicated; but it is estimated that $\$ 50 \mathrm{~m}$ a year goes into film funding. Despite this, and the 20 feature films made annually (an appropriate number from a country with our population) all we hear on every side are complaints about government 'cut-backs' and indifference to the arts.

So what should we expect to see? Is it too much, too narrow, too parochial, too nationalistic, to then expect that a Canadian film, financed by us, by the state, should be recognisably set in this country and identified 
as such, written by Canadians, and portrayed by Canadian actors? Many are, but the matter of where they take place is usually blank. The reward of self-recognition among audiences is rare. Private producers who raise their own money are entitled to make whatever rubbish they want, set wherever they please -- usually in the US; but, for the money Telefilm and the little telefilms spend on films, we expect something close to our lives and identity. It is true that some of the films return part of their grants, leading Telefilm to say that it is only interested in commercial productions in order not to lose our money.

How kind, but to make deliberately contrived commercial films usually results in making trash, such as The Assignment, and none of us I think wants to see our money spent supporting profit hungry producers. Commercial films do not necessarily mean bad films (consider The English Patient, Shine and Big Night -respectively British, Australian, US) which were not conceived as moneymakers, but as genuinely creative works their makers believed would appeal to an intelligent audience, recover their costs, leaving enough to start their next film. Telefilm is usually silent when films of this nature are proposed here. What are films expected to do other than to entertain their audiences and make money for their producers? It is quite customary these days for films to be recognised as being both an art and a business. Filmmaking is not an industry (Stelco and General Motors are 'industry') although people working in films constantly refer to filming as "our industry". As an art, films are living pictures, true or false, of the countries and the people they represent. Whether it is Ron Howard or Mike Leigh, audiences know what nationalities are being portrayed and where they are living. Now consider Canadian films -- other than those made in Québec -seldom will one in ten let an audience know that the story is taking place in Canada and that the characters are genuinely Canadian. We might assume this to be so because we have been told that the film in question 'is Canadian' because it was filmed here. But nothing on the screen will let us know and perfect strangers going to see a Canadian film would never guess that it is one unless they sit patiently through the end credits and discover that the frequently American-looking and sounding film they have seen was made possible by Telefilm.

In 'ROC' films, the characters never talk about where they come from or mention where they are going. The very thought of dialogue saying "I'm from Alberta" or "I'm going to Newmarket" never crosses a writer's mind or if it does the producers will probably remove it. No one in our films is seen reading The Globe and Mail or the Toronto Sun (in a recent film, a bundle of newspapers being delivered was turned upside down to avoid revealing its name), no radio announcer is ever heard to say "This is the CBC." -- a recent exception being Nothing Too Good for a Cowboy. The police are seldom identified by their actual uniforms and the cars they use, no politicians are ever mentioned, no hospitals, schools or public buildings are identified, and seldom a maple leaf flag is seen flying. Contrast this with what we see in American and Québec films. Their filmmakers are delighted to be proud of their places and their society and put it naturally on the screen. Montreal lives constantly as do other places in the province used as locations; when people go abroad and say that they are from Canada the usual response is "Oh! from Montreal?" No one ever asks if a Canadian is from Toronto because no one has ever recognized it on the screen, even although they may have seen flashes of it. The CN Tower should be as well-known as the Eiffel Tower or the Empire State Building, but it is not and the way we hide everything it never will be. Even a silly but outrageously black Vampire comedy from Québec called Karmina gives us a customs inspector saying "Welcome to Canada" and when money changes hands the $\$ 5$ bill is clearly Canadian, not hidden and not American -- as it usually is.

The public attending American and British films, European and Asian films with sub-titles, go to see them expecting to see the homes, the streets, the backgrounds, the habits of these countries and their people. They are not disappointed. They don't expect to see non-American films aping Hollywood or taking place in a 'never-never land'. Audiences are forever curious to know more about the places they see while being absorbed in their stories. And in the business of tourism, these countries benefit considerably as people take their holidays in the places they saw on the screen and attracted them to see more of these settings. Thousands of people travelled to Egypt to see where The English Patient took place only to discover it had been filmed in Morocco! Thousands went to see Scotland, the land of Rob Roy and Braveheart, although more of the latter was shot in Ireland. But the strength of identity cannot be denied. With Canada you draw a blank. Among recent films, Bruce McDonald did identify in large letters across the screen the cities in which his Hard Core Logo takes place, but in this case, considering the nature of the story, they would probably have preferred to remain anonymous. 
Consider Egoyan's latest film, The Sweet Hereafter, the outcome of which, in ironic terms, is not intended to be sweet, now or forever: this picture came to us on a great wave of adulation, first because Egoyan actually adapted a novel instead of writing his own screenplay and second because the Cannes Jury, notorious for handing out awards to unworthy films, gave it a Prix Spéciale. As we are now attuned to so much in our lives being American with American references, both visual and spoken, written and performed, being so prevalent in our daily existence and constantly in the media, no one was surprised when Egoyan announced the book he was adapting was American. We sympathized with him knowing how very few Canadian books are published these days leaving little to choose from to adapt to the screen! Being an American book there was nothing ambiguous about where it takes place. But wait, Egoyan announces triumphantly that he is changing the setting to Canada. That should please us -- after all, there's not that much difference between us and our neighbours -- or is there? So the film comes out and everyone exclaims with delight on seeing the mountains of British Columbia. Awe inspiring, say the critics; how marvellous -- out of relief no doubt as a respite from seeing our scenery, from Nova Scotia to British Columbia, being passed off as being American places in American films made up here in Hollywood's North.

But how Canadian is The Sweet Hereafter? Not at all. We only know it is Canada because we have been told that it was filmed in British Columbia. How do we know that these are our Rockies and not those South of the border? The story concerns a lawyer who arrives, of course, as do characters in other Egoyan films, from nowhere. "I'm a lawyer", says the accomplished British actor, Ian Holm, not, as he would in every other countries' films, adding the name of his city. No one he speaks to asks where he comes from or inquires about his background. We are told repeatedly that he has come to serve the community, but we never see a community, never a main street, never a town, only a carwash. The sorrowing parents he has come to assist, who have lost children in a school bus accident, are hard to believe. The actors have dialogue which is for the most part meaningless and repetitive as he talks to the main families involved, and they are hard put to know the characters they are playing. He drives up mountain roads and driveways to the isolated homes of parents and to a motel. All of this will be explained by the directors' admirers as being part of his style in which to be universal in expression means being nowhere. The narrative is moved forward only minimally until a daughter's confession at the end supposedly puts events in their proper place but by then the audience is hardly likely to care. Some characters are seen once and disappear. The marvellous Alberta Watson is brought in for the obligatory sex scenes. The characters, as with those in Egoyan's previous films, have no depth and no real identity. His narrative power is weak, his stories incomplete and superficial.

Adding meaningless passages to his dialogue from The Pied Piper only intrudes on an already excessively talkative screenplay. Ian Holm, trying on a peculiar accent which comes and goes, is clearly wondering what, and who, he is and why he came to these freezing mountains. The winter scenery is certainly beautifully photographed by Paul Sarossy but this is not supposed to be a travelogue. It neither contrasts with nor complements anything in the narrative other than to point out the obvious: that nature at its most beautiful is also deadly. The story is broken up with awkward flashbacks and flash-forwards, the primary ones showing the lawyer on an airplane. Not until the end do we know he was flying home -- and we don't know where that is either. There is little that is believable about this film whatsoever; as for the grieving parents, they might well be talking about taking out an insurance policy. Are these truly people of British Columbia? There is a reference made to the National Weather Office. There is no such body in Canada. Could they not have said they were speaking to Environment Canada? Or would that have choked Egoyan? The lawyer, an unhappy fellow with his own family troubles, tells the parents that he will work on a commission, charging nothing if they lose the case (it is never clearly enunciated who they are going to charge for the accident). Some of the legal practices shown are not legal in Canada. There are only minor references to Canadian identity which one suspects slipped in by accident or as a token gesture to the picture's origin. A schoolchild is shown briefly passing the camera wearing a coat with a maple leaf, and one parent, a physically handicapped husband in a wheelchair who does an embarrassing rant over the accident, is wearing a blazer with the Royal Canadian Legion crest on the pocket. But few will recognize it. Critics will airily dismiss all these concerns as being foolishly petty and unimportant. Egoyan is above realism and naturalism. His view of society and individuals comes from the abstraction of the inner places of his soul, the intricate workings of his mind and his explorations of the dark passages of human perception and warped sexuality. This is pure bunk of course. As with his previous work this film is dead from beginning to end. 
In the matter of a country's identity let us just consider American films. Why is it the US is so well known abroad? Because, quite obviously, American films, shown and finding popularity everywhere, are clearly American in the depiction of its people in all walks of life. How many Presidents have we seen this year? More than six. How many of our Prime Ministers have we seen over the past fifty years? None, only occasionally in newsreels and documentaries. Films are for the most part a realistic medium. In those which are not based in reality, as are fantasies, impressions or experiments, one does not expect to see actuality. But what we are dealing with is the mirror held up to life as we recognise it to be -- if not to know.

The Sweet Hereafter opened The Toronto International Film Festival last year. All other new Canadian films were placed in the Perspective Canada programme. This was opened by The Hanging Garden, by first time director, Thom Fitzgerald. The rapturous reception it received from the media and the false school of Canadian nationalism widely over- estimated the film's talent and intelligence. Greeted with admiration as being a "film from Nova Scotia" no one would know it anymore than one would know that The Sweet Hereafter was from British Columbia, had they not been told it was filmed in the province, as everyone was at the festival. Typically, it could have been taking place anywhere -- yet nowhere. There was nothing in the background, or foreground, or in the dialogue, to indicate that Nova Scotia was the setting. It might have been upstate New York just as The Sweet Hereafter could have been Washington state. The complicated narrative, not well devised or told, is about a gay son who returns home (from where we do not know) to attend his sister's wedding. Later he talks briefly about having worked for a radio station -- W something, which did not sound Canadian. (There is never any hesitation on the part of screenplay writers, and no doubt producers, to mention American references in their supposedly Canadian films.) The man his sister is marrying is bisexual and the brother's previous lover. They have a rendezvous the night before the wedding. The sister seems to know of this relationship but it doesn't seem to bother her and is heavily into the use of "fuck". It is everyone's second word in conversations in most of our films today. There is no one in this torn-apart family to believe in, to relate to, except the put-upon wife and mother, who seems too young for the role. Are there really people in Nova Scotia who behave like this? At the end the brother leaves -- to go nowhere apparently. MGM, desperate for "product" (a terrible Hollywood term for its motion pictures) bought the US rights to this picture for $\$ 500,000$ but critics detached from the hysteria surrounding The Hanging Garden doubt that it will return this investment. (Filmed partly in Nova Scotia is the British film Love and Death on Long Island with the province being used to represent Long Island. The background doesn't ring true. Nevertheless, the critics and trade alike joyfully describe this too as a Nova Scotia film!)

Talk of unity and identity among Canadians seems to take up an enormous amount of space day after day in the media and in political debate and discussion. Some columnists have made a career writing about the issues, so much so that the public is tired of it and it has become meaningless. In the once not too distant past the public seldom worried about such matters. Canadians knew who they were, no matter in what provinces they lived. They went to their cottages in the summertime, enjoyed (Dominion) Canada Day, and made the most of winter pleasures. Today it is hard to avoid being suffocated in flags and dreary speeches from Ottawa exuding patriotism and telling us what a wonderful country we are living in. Back in the past we let the Americans celebrate their 'freedom' four days later -- we had fish to catch and lakes to swim in, the CBC to listen to, Export A cigarettes to smoke, Maclean's and the Toronto Star to read -- or the daily papers of other cities; and no one twisted themselves into knots wondering who they were and where they were. When therefore, our film producers came on the scene during the fifties they were afraid that such symbols, references and practices, even the people themselves, would be dull subjects to form the basis of profitable movies. Our young independents of those days, Don Shebib, Larry Kent, Don Owen, Alan King, Zale Dalen and William Fruet who had made a fresh and likeable beginning, were left behind. And our English-track producers, the so-called big players, together with owners of private tv stations, thinking then, as they do now, only in terms of the US market, adapted the "international look" -- meaning the American look -- and stripped away any references to Canada substituting Americanisms instead and passing off Canadian places as being American. This led to a certain amount of public criticism forcing producers to drop overt American references leaving their films to take place in "never-never" lands. Characters however continued to wear T shirts with American references on them, but, it must be admitted, this does not seem to worry the public at large particularly the younger generation, nor the critics who seem to think that anyone pointing this out is somewhat small-minded indeed. 
The influence of American entertainment has resulted in many Canadians, young and older, wearing clothing advertising the fact that they support US sports teams, watch US TV programmes and have visited exotic places south of the border which they have seen in US films. The public at large does not appear to be overly-concerned about this drift, as shown by so few of them bothering to see Canadian films, most of which are shown by Cineplex-Odeon, because they lack wide appeal. As for the critics, many seem to positively revel in the fact that Canadian films remain largely anonymous in the lives they portray. Nonsense, they say, of course they are Canadian; it is the spirit that counts. Canadian sensibilities (whatever they are); the very essence and atmosphere of Canada is in the work of our filmmakers, every one a hero, even if they never show these qualities.

The fact that Australian and British filmmakers, without drawing back for the sake of "their international audience" and overseas sales, never hesitate to make references to their lives and places and people in terms some foreign audiences might not even recognize, doesn't deter the public from seeing them. And audiences accept ambiguities of this kind as being a charming and integral part of the lives they are watching. If the narrative is strong, local references are not a bewilderment destroying the whole. But to this day producers are resolutely opposed to making English-speaking Canadian films contain anything that might give away their origin. And have they found success as a result of this in selling their films to the US? Absolutely not, but they never learn and continue to deny us the very trappings of life which make us what we are. Our television companies, with some exceptions, are just as greedy and power hungry. They have made the term "Can-Con" ridiculous (it was ill-conceived in the first place) going to great extremes to convince the CRTC of their good intentions at licence renewal time, not meaning a word of it, and then doing all they can to show more American programmes. One would think that being Canadian themselves they would want to make, encourage, and show Canadian programmes and films and be proud of it. The Americans would never sell themselves out as our film and television producers do. As a result the public has come to accept American programmes and films as being our tv and films because we spend so much time watching them in a society permeated with American habits and practices. We accept them, along with heroes and villains, as being us.

As for our filmmakers they continue to be exonerated of such behaviour by the critics: Why should Egoyan be any more specific than he is? He is a great artist, his places are places in his mind and imagination . He has no new clothes but we must believe that he does, every time he makes a film; we should understand that when Ian Holm is unrealistically trapped in his car during a wash with water streaming down the windows this is the transference of the tragedy yet to come of the children drowning in the school bus (whom we never see) when it sinks through the ice. The lawyer is drowning in his own misery, but such symbolism is poorly conceived and carried out because Egoyan lacks a truly cinematic mind. Art being what it is today all his failings are mistaken for strengths. Recently he expressed his weariness with his films: his characters, he said, "were becoming predictable" to him. Most audiences do not even understand them. He is expected to leave soon for Los Angeles (his last visit did not bear fruit) to make a picture for Mel Gibson's Time Warner unit which has given him, according to Egoyan, "Final Cut." The result should be interesting.

The Canadian film programme at the Toronto International Film Festival is called Perspective Canada but what perspectives the films have on Canada as a society, in art or life in general, remains for the most part limited and unsavoury. You could sum them up as being gangsters, garbage and gore. The same tired phrases are heard in reference to many of them -- disenchanted youth pursuing their "culture" and sexuality, portrayed in shallow and simplistic terms. Positive standards in moral behaviour are hard to find. If the movies chosen were presented as being a review of film making in this country over the past year, the good, the bad and the indifferent, shown to let audiences know what we are doing with largely public money, we would find it perhaps a useful even though disappointing service. But a great deal of money is spent on selecting and programming these films; to justify this, they are described in the catalogue in favourable terms they fall far short of achieving.

An odd documentary, for example, which is in itself a metaphor for our domination by the American cinema and its strong influence on young filmmakers in this country (not so much abroad it would seem) is the student-like Pitch. This is a series of foolish encounters taking place during the search by two real-life and somewhat obnoxious Canadian filmmakers, Kenny Hotz and Spencer Rice, to interest American filmmakers in providing them with a budget to make their "comedy" about a Mafia man who goes into hospital for 
a hernia operation and by mistake is given a sex change operation. And so they bother everyone at last year's film festival who is in the business of film (Roger Ebert sees through them) and are given a mixed reception. Some executives take the time to listen, others are understandably impatient. Later they go down to Hollywood and bother more lesser film types who scratch out a living on the edge, and wonder why the studios will not see them or read their script. Two aspects of this tiresome endeavour are clearly present: one being that their film courses at universities were clearly incomplete if their instructors did not inform them of the ways and means of trying to get a film financed, (what they were doing was the worst of all possible methods) and secondly as young Canadians they obviously gave no thought of trying to make their film Canadian. Speak to any would-be filmmakers in the "ROC" and their models are all American: Kubrick, Scorcese, Lucas, Stone, Spielberg, which is not to be despaired of if these models inspire them to use whatever talents they may possess to make Canadian movies rather than imitations of American films.

An encouraging contrast to the behaviour and outlook of Hotz and Rice is Hayseed, a genuine attempt at comedy -- unusual for a Canadian film, despite how many great comedians we have -- quickly made, by two students, Joshua Levy and Andrew Hayes, with credit cards, hard work and enthusiasm; and is largely successful in its parody of two young innocents who leave the countryside for Toronto and survive, with fairy-tale improbability, life in the wicked city. As might be expected from a film made under desperate conditions it doesn't always work, but when it does, which is most of the time, it is keen and hilarious.

We have embraced idiolatry within our small clutch of filmmakers with such fervour, tinged with fear of failure, that it is impossible to speak of any of them without exaggerated claims to their skill and importance. Certain directors are described as "daring", "acclaimed", "internationally famous", with every minor film festival award triumphed as a major distinction. Several of the films in the Perspective require the reading of a synopsis before their intentions become known. City of Dark, for example, from the NFB by the experimental director, Bruno Lazaro Pacheco, is about a "research scientist who has developed a computer system capable of scanning and displaying subconscious memories". Pacheco has managed to "withhold enough meaning" in this "moral dilemma" within an "unfolding mystery". Audiences should know that "they are lured away from our penchant for immediate plot-line and structure" allowing them to come to terms with a dark and dismal future. It does not 'unfold' much that is plausible at any level, it hardly seems to justify NFB support in these times of financial restraints, and only the sharp black-and-white photography gives it a sense of a lost reality. Its audience will be few in numbers and will likely be as perplexed as those who go to see Cube.

This piece of self-indulgence comes from the Canadian Film Centre, and is hardly an example of works "telling our stories," dealing as it does with a group of mixed individuals who find themselves trapped in a Cube, escape from which only leads them into another cube, and another, and another. There is no explanation for any of this and nothing profound in the dialogue leading us to believe that life in a cube is filled with deep and significant meaning. The young director, Vincenzo Natali, told the press that he thinks he and his writer are describing their own lives: "nothing was going on and we were trapped in this little room trying to find a way out. I think it's due to my own internal claustrophobia". Audiences will probably be finding their way out long before the end comes in sight. There is no truth to the explanation that the Cube's passengers are a group of lost Canadian astronauts; the design and construction of the Cube however is better than anything taking place within its walls, but then perhaps it is all computerized.

At least none of the "trapped ones" appear to be played by Americans which is a pleasant change. Those moviegoers who do see Canadian pictures must be mystified as to why American players are involved particularly as we have so many good actors of our own who are mostly under-employed. The majority of the Americans in Canadian films are little known, or Hollywood has-beens, usually being used by our producers under the mistaken impression that they add to the box-office appeal of the films they are in. They never do, but again producers never learn and never give up this silly pursuit. It is surprising, however, to find several American and British players in Guy Maddin's new film, Twilight of the Ice Nymphs as he is not by any means a commercial filmmaker. He has always been an experimentalist with a difference, whose outlook on life is that of a permanent fairy tale, and his films have the mystery and style of fables and fantasies. His audiences are small and loyal but they may be even smaller and much disappointed with his latest and, he thinks, pessimistically, his final picture. His world this time, known as Mandragora, is one of cardboard sets and banal dialogue where its people experience the cruelty of love, and the passions, fears and nightmares of strange relationships. In other words, obscurity at every turn. Even the experienced R.H. Thomson, one 
of two Canadian actors, cannot hide his bewilderment over who he is and what he is doing in this film.

From this we are thrown into Cut, yet another immature piece from John Greyson, described as a film essay "on circumcision and copyright", and dragging in -- as was Sir Richard Burton in Greyson's The Making of Monsters -- an unsuspecting Pierre Trudeau. Nothing makes sense in this hodgepodge of homosexual references and "playful politics". It's time Greyson grew up, although what will be forthcoming then is hard to imagine. The opposite side to this kind of being playful and of wanderings in dark places is found in Clement Virgo's gentle picture The Planet of Junior Brown. The script provides its share of bafflement, but Junior Brown is a likable overweight black teenager who loves food and music, and whose mother destroyed his piano. He continues to practice by playing imaginary keys on the kitchen table. He and his friends seek solitude from the crowd losing themselves in a model of the solar system where Junior Brown becomes enchanted by the music of the spheres. At least the emotional experiences of these young people are real and honest, although it is an intimate world difficult for certain audiences to enter.

In this festival program there is little to raise the spirits or make one feel proud of Canadian cinema. We constantly hear from the never-give-up supporters of Canadian-films-at-any cost that recent works of young filmmakers met with "standing ovations" at festivals around the world and 'thrilled millions" wherever they were shown. This is of course what has come to be known as 'media hype'. Consider the overpraised Mina Shum (who made Double Happiness two years ago) who returns highly acclaimed with Drive, She Said, her subject being criminal activity, sex and violence. This is a favourite mix of topics, with younger directors. After a promising opening sequence depicting a bank robbery, a teller is kidnapped and the story goes on the road to nowhere. Our expectations quickly diminish as the plot loses its way in the failing narrative and collapses in a series of improbabilities. Kitchen Party by Gary Burns -- who made the slight and tedious The Suburbanators two years ago -- may or may not be taking place in Calgary, or is it Vancouver? and takes a farcical look at the gulf between unhappy middle-class parents and their spoiled and unloved adolescent children. As in many American films a gun becomes a prominent story prop and melodrama and low humour are rife. At times the young players are not without credibility.

And melodrama comes in spades in Shopping for Fangs, by Quentin and Justin Lin, a ridiculous concoction of horror and contrived humour, set and filmed in California, with nothing about it which makes it eligible to be called a Canadian film other than the nationality of its makers. (Last year's 'Canadian' film of this kind was Five, made in India by Deepa Mehta.)

But the worst is still to come. Men With Guns by Kari Skogland is a violent and evil picture of brutal criminals whose behaviour is depicted not to elucidate our understanding of what is wrong with society but to relentlessly and deliberately exploit them in terms of sheer and unadulterated sensationalism. That our producers can sink to this level of obscenity is discouraging. Its only purpose is to make money on the video market. It will not, because the Americans have enough of their own bad films without taking ours. Why an abysmal work like this should be considered worthy of being included in Perspective Canada is not explained.

Regrettably, wallowing in violence and evil and slavishly copying Hollywood at its most vile has infected Québec cinema, resulting in absurd stories about murder and corruption in high places. Alluding to subversion among our established organisations can be thought-provoking and provide warning signals over allowing complacency to dull our awareness of it; but to deliberately try to shake our faith in them with dishonest, far-fetched plots about bribery, murder and widespread corruption within the establishment has become pointed, crude and vicious. Last year we had Black List, a wretched piece in which all the Québec Superior Court Justices were involved in sex, drugs and murder; this year we have La Conciergerie des Monstres (The Keeper of Monsters) by Michel Poulette, an ugly, abhorrent and poorly scripted melodrama about police duplicity and university complicity. But although these films are set in Québec the number of references to things American in Québec films increases rapidly and the number of American cities used in the titles of Québec films is quite dismaying. They have little if any meaning and do not bring about increased showings in the US.

Fortunately decency prevails in Andre Forcier's La Comtesse de Baton Rouge, his own story of being part of a Montreal "Circus of Happiness" which travelled to Louisiana in 1968. As in most of Forcier's work he uses cinematic techniques in moving between time and place, past and present, in flashbacks and other imaginative devices, to depict with several biographical references the life of a young film student who falls 
in love with the Bearded Lady. This is a picture filled with love and romance, working perfectly within its complicated but controlled structure, and continually surprising in its depth of passion and fantasy. In its sometimes abstract but telling interpretations of creative forces and its feelings of sadness over a lost past, it makes us painfully aware of a future that might have been. La Comtesse de Baton Rouge represents the best in Canadian cinema; but the critics here ignored it. Andre Forcier, one of its established directors, has thankfully endured under the wave of new young directors whose attributes are questionable. But six of them in Québec acquit themselves well in Roger Frappier's Cosmos. Here a Greek taxi driver links six unconnected short stories of various individuals and their activities in a bleak, black-and-white, winter-time Montreal.

There are continual complaints being vented by the 'cultural activists' about why our films have such a tiny audiences. They blame Hollywood for taking up so much screen time leaving us with only 3 per cent -the figures change from time to time depending on who is making the charge. They seem to forget that if the cinemas did not have American films to show they would be forced to close down, putting thousands of employees out of work, because we cannot fill the screens. And in the time presently taken up by our films the results are usually dismal in financial returns. The audience appeal of many of them is so limited they are lucky to get a showing. For Sheila Copps (the Federal Minister of Canadian Heritage) and the Canadian Conference of the Arts to squawk over Sony taking over Cineplex and becoming alarmed about the showing of "our films" is nonsense. They are inconsistent in what they are talking about; Sony may not be as kind to our unappealing films as Cineplex-Odeon has been, and as for Famous Players it is giving The Sweet Hereafter a good run for its money. The activists continually berate the Federal and Provincial governments for cutting back on financing for filmmakers. Most of them, as with so many so-called artists in other disciplines, are not worthy of public funding. Many who deserve to be supported are turned down by committees unqualified to judge whether a script will make a good film or not.

Then of course we have the activists railing over the Federal government selling our "cultural industries" under the Free Trade Agreement. But no wonder the Americans will not accept that our films need special protection. They must look with incredulity at the mostly awful stuff we are turning out under the guise of culture and clearly labelled in the credits as being supported by "The Government of Canada", "The Government of Québec", "the Government of Ontario" and so on. They can only come to the conclusion that we have a state controlled film sector much the same as the communists did during their time in power in the Eastern Bloc. Except we have a government so weak that it doesn't insist that publicly-funded Canadian films should reflect Canadian life. What we have now is a welfare state for well-off producers safely encased within certain big companies, such as Alliance, Atlantis and Nelvana, Cinar and Allegro, who are mainly service agents for American networks and movie producers being assigned "movies of the week", mini-series and knock-offs of old US television series (Hitchcock, Hitch Hiker, and numerous sci-fi shockers and animated series). There is no joy in creativity for these producers, no satisfaction in putting Canada on the screen. Their rewards come purely in financial terms. As long as the cash rolls in they will continue to make a few token Canadian films or tv programs, the latter mostly in the American mould (Traders, Due South). Still others, the smaller players, concentrate on more non-Canadian subjects. The business of film is one of greed; soulless and without vision, our identity lost and national revelations entirely absent. A competitor is now on the way in the form of Lionsgate Films of Vancouver. They have announced their intention of making Canadian films; they will no doubt produce films in Canada but it is unlikely they will be about Canada.

Even sadder are critics and reviewers who insist on upholding much of the mediocrity which passes for Canadian filmmaking as being unmistakably Canadian in the best sense. The strange and the weird, we are informed, reveal our fixations with death and despair, madness and morbidity. These characteristics are our strengths. This is nonsense. One becomes as tired of this as forever being reminded of Margaret Atwood's Survival. If this is what we are we do not amount to much in this teeming electronic universe; but conversely, the independents at the low end of the scale, are not much better. We hear how badly Telefilm treats them, how they are pushed into corners, bullied by Hollywood practices, but no one seems to think that most of them are poorly equipped to make films in the first place and would not be in a position to do so were it not for misplaced government financing. Meanwhile, the provinces continue to prostrate themselves before Hollywood in their continued eagerness to have its filmmakers come to them to make their movies and take advantage of our cheap dollar. We sell them our scenery and our cities rather than make them our own. 
Halifax now has its own studio to support its "film industry". Well, cheers, but to make what? Films about Nova Scotia? We live in hope. Ken Pittman and William MacGillivray have been ignored for too long.

Perspective Canada has not been a fulfilling or uplifting experience when only a small number of films out of the more than twenty shown can be described as finished and intelligent creations. Back in the sixties the Montreal Film Festival contained a special section for Canadian films because they were not considered strong enough to rank with international entries. Now that film making in this country came of age years ago it should not be placed in a ghetto, but allowed to stand beside the best of those from around the world. The fact that they cannot, that special exceptions should be made for them, is a dismal acknowledgement of our failure to match the best from abroad. Misplaced is the enthusiasm shown by the younger generation working in our festivals for work obviously inferior and flawed in the making. Have they any knowledge of film history? But shortcomings are perceived to be their strengths and we are given a bewildering interpretation of what so many of these films mean even though they give little indication of such qualities. One wonders how effusive praise continues to be heaped on them when their weaknesses are cruelly revealed shown side by side with inspiring and humanistic new creations from so many other countries. But the boasting continues; they are selling by the hundreds abroad making fortunes and being seen by millions of viewers. We are living in the same never-never land as most of our films.

What is the answer then to what we should expect from our films? Surely this is obvious from what we see in the best from abroad: lively, humorous, affecting studies and considerations of real people in honest and revealing stories about this country, made with feeling, concern and imagination by talented individuals who know what film making is all about. Film is the modern means to express in subtle and significant ways the spiritual and emotional ideas, thoughts and beliefs which artists through the ages have tried to convey to influence and change society. The only artist to have done this recently is Robert Lepage with The Confessional and The Polygraph. These two films however, were made over two years ago. There has been nothing to match them since. Where most of our films are concerned audiences find it impossible to relate to, or believe in, any of the characters portrayed. Distinctive human personalities, whether good or bad, are hard to find meaning that genuine humanism is at a low ebb.

As the 1998 begins we again hear Sheila Copps indignantly chattering on about what she is going to do to improve the "distribution" of our films to our cinemas. She is appalled that "so few get shown". What she is referring to is exhibition and in this she doesn't know the first thing about the film business. Has she actually seen all the Canadian films she is so anxious to have shown? Overcome by feting Egoyan on Parliament Hill she thinks that we are bursting at the seams with creative filmmaking and being unfairly treated by Hollywood. If she opened every Canadian film made last year in our cinemas, most would be empty. The place for the best of our films to be seen today by the public across the nation is on television -without being ruined by commercial interruptions. But does the $\mathrm{CBC}$ show the way? Hardly, look what it does to its own productions. Through its taxes the public pays to have films made and it pays for the CBC to show them; but our "public service" broadcaster will not find the money to show them to us without breaks. It could if it cared to but it doesn't. It likes to look and behave as the US networks do; it is one of the ultimate symbols of our acceptance of doing things the American way, in this case within the world of film and television.

Many observers in the trade believe that Telefilm must take more positive steps to improve the quality of most Canadian films by taking them out of the clutching hands of the young and inexperienced auteurists who insist on writing their own scripts lacking ideas, characterizations or structure in their narratives. Telefilm could do this by using the huge sums of money it gives out in script development (and in the reading of the hundreds of scripts, mostly useless, sent in each year) to take options on the many filmable books published annually in Canada and calling on script writers (many of whom do not work because they are not auteur directors) to adapt stories of their choice, then propose them to directors to choose whatever subject appeals to them. In this way, Telefilm's far too easy acceptance of scripts, many entirely lacking in Canadian identity, would be replaced by a distinctly Canadian pattern of filmmaking.

It is obvious that something must be done, how else to explain why two films made in 1970, Going' Down the Road and Mon Oncle Antoine remain, in one critics' poll after another, the two Best Canadian films? 


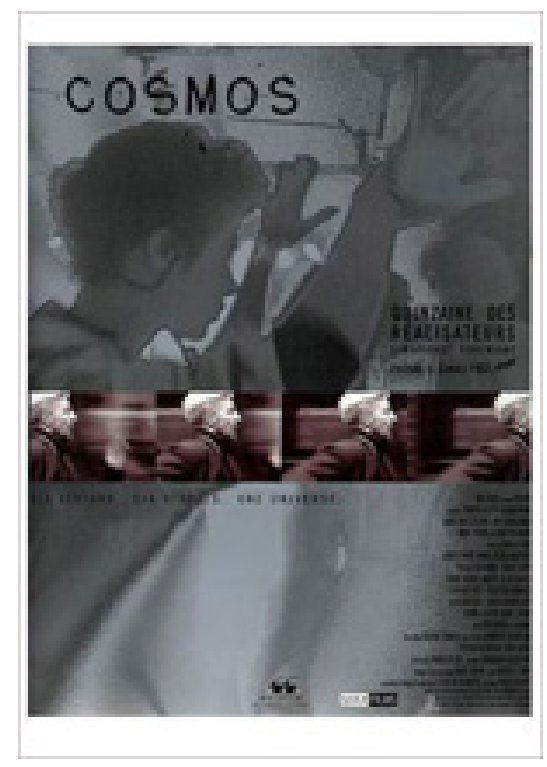

Figure 1: Cosmos (Jennifer Alleyn and Manon Briand, 1996)

\section{Author Information}

Gerald PRATLEY, OC, LLD, started his career as film critic with the CBC. In 1969, he founded the Ontario Film Institute which he directed until 1990. He has written several books and numerous articles on film, including Torn Sprockets, a history of Canadian cinema. He taught Film History in universities in Toronto and Waterloo, Canada and holds three honorary degrees from Canadian and US universities.

Gerald A. Pratley (1923-2011) was born and educated in London, England, and came to Canada in 1946. He started working in Toronto for the $\mathrm{CBC}$ as a scriptwriter. He was drawn toward working in motion pictures, and became, in 1948, the CBC's first film critic and commentator.

Gerald Pratley broadcast three programmes a week, Pratley at the Movies, The Movie Scene, Music From the Films, and others, until 1975. During this time he also became the first post-war chairman of the Toronto Film Society, chairman of the Toronto and District Film Council and co-founder of the A-G-E Film Society and correspondent for international magazines such as Films and Filming, Film In Review, Variety, Hollywood Quarterly and International Film Guide. During the 1950s he wrote for Canadian Film Weekly and Canadian Film Digest.

He became known as a speaker on all aspects of motion picture art and industry, and was invited to teach film history at the University of Toronto, York University, University of Waterloo, Seneca College and Ryerson Polytechnical University, with individual lectures being given at many other Canadian and US universities and colleges. He has served as a member of various judging panels of competitions and festivals, being one of the members of the first Canadian Film Awards in 1949.

From 1970 to 1975 he was the director of the Stratford (Ontario) International Film Festival, and from 1969 to 1976 he was Chairman of the International Jury of the Canadian Film Awards. He has attended all the world's leading festivals of film, and in particular, for 30 years, the Cannes Festival as CBC correspondent. He has written six books, The Films of Frankenheimer: Forty Years in Film; The Cinema of John Frankenheimer; The Cinema of Otto Preminger; The Cinema of David Lean; The Cinema of John Huston, and Torn Sprockets, a history of the Canadian cinema.

Gerald Pratley has served on the Advisory Boards of the film departments of Ryerson Polytechnical University and Humber College, and as a member of the programme committee of TV Ontario. In 1968 he became the founder-director of the Ontario Film Institute of the Province of Ontario, an organization which has distinguished itself in archival holdings and public service and is known since 1990 as the Cinematheque of 
Ontario. He taught Film History courses at the Department of Film and Photography, Ryerson Polytechnic University, Toronto and the University of Waterloo.

In 1984, Gerald Pratley was made a Member of the Order of Canada and in 2003 Officer of the Order of Canada for his service to Canada through film appreciation. He holds Honorary Degrees in Letters and Fine Arts from York and Waterloo Universities (Ont., Canada) and Bowling Green State University (Ohio, USA).

In 2002, Gerald Pratley received a Special Genie Award from the Academy of Canadian Cinema \& Television in recognition of his lifelong dedication to the promotion and his exceptional support of Canadian cinema.

He died on 14 March 2011 in Ontario, Canada. 